\title{
Susceptibility of Certain Citrus Varieties to Infestation with the False Spider Mite, Brevipalpus obovatus (Donnadieu)
}

\author{
Azza, A. Mohamed; Ghada, S. Refafi and Safinaz, A. Ahmed \\ Plant Protection Research Institute, ARC, Dokki, Giza, Egypt.
}

\begin{abstract}
The three tested citrus varieties marked variation in their susceptibility to Brevipalpus obovatus infestation. Susceptibility indices calculated for each variety showed that the mean number of mite populations of the three tested citrus varieties recorded few individual during the first period of observation; while later reduction in mite population was recorded on all varieties from December to April during the two successive seasons, 2013-2014 and 2014-2015. Thereafter, a significant higher mite populations was recorded reached a peak during August for the three citrus varieties with a total number of 261 and 298.33 mites/sq. inch on common Balady orange, 219.67 and 259 mites/sq. inch on Washington navel orange and 185 \& 239 mites/sq. inch on common Mandarin orange during 2013-2014 and 2014-2015 seasons, respectively. Accordingly, common Balady orange variety was the most susceptible for mite infestation with an average number of 83.16 and 89.02 mites/sq. inch; while, least infested variety was common Mandarin orange with rates 42 and 59.5 adults/25 leaves, during the two studied seasons, respectively.
\end{abstract}

Key words: Susceptibility; Citrus; Brevipalpus obovatus; Tenuipalpidae.

\section{INTRODUCTION}

The genus Brevipalpus is considered one of the most economically important tenuipalpid species on citrus in different parts of the world. Brevipalpus californicus, B. obovatus and B. phoenicis have all been identified from citrus in Brazil, Costa Rica, South Africa, Egypt and United States (Muma 1975, Smith Meyer 1981, Ochoa et al., 1994). The most significant threat posed by these mites is as vectors of a potentially invasive viral disease called citrus leprosis (Childers et al., 2001, Childers et al., 2003 a\&b and Sánchez-Velázquez et al., 2015). Citrus leprosis is a serious virus disease that can ultimately kill citrus trees (Rodrigues, 2000 and Sánchez-Velázquez et al., 2015).

Many Brevipalpus species reproduce by theletokous parthenogenesis; while other species reproduce by male fertilization of female eggs. Previous researchers have determined that Brevipalpus obovatus Donnadieu, females were haploid. Development rates are strongly influenced by temperature, relative humidity and host plant (Goyal et al., 1985, Childers et al., 2001and Mata et al., 2010).

To characterize the dynamics of the probability and the rate of B. obovatus infestation in response to host plant, considerable research is needed. Therefore, this study was conducted to identify the susceptibility of certain citrus varieties to infestation with false spider mite, B. obovatus under field conditions.

\section{MATERIALS AND METHODS}

The field experiments were carried out in sweet orange orchards at Qalubia Governorate, during the two successive seasons $2013-2014$ and 2014-2015. The study dealt with clearing susceptibility of certain citrus varieties to $B$. obovatus infestation. These varieties were common Mandarin orange, Washington navel orange and common Balady orange.

The experiment was conducted in complete randomized distributed orchards; we sampled 3 orchards that were located at different locations at Qalubia governorate. Samples of 25 leaves were taken from each of five trees within the orchard and returned to the laboratory. The trees were selected based on their position in the orchard, one from each of the four corners and one from the center. Samples of the plants were picked up from each variety randomly at weekly intervals to assess the numbers of mites.

In the laboratory, the total number of mites was counted and collecting using a fine brush for identification and analysis using a binocular stereomicroscope. Normal agricultural practices were carried out without any application of insecticides.

\section{RESULTS AND DISCUSSION}

In This study we investigated the susceptibility of certain citrus varieties to infestation with the Tenuipalpid mite, B. obovatus under field conditions. Obtained results showed that the mean number of mite populations on 25 leaves of the three tested citrus varieties showed few individual during the first period of observation; while later on, a reduction in mite population occurred on all varieties from December to April during two successive seasons 
2013-2014 and 2014-2015. Thereafter, data recorded a significant higher mite populations reached its peak during August for the three citrus varieties with a total average of 261 and 298.33 mites/sq. inch on common Balady orange, 219.67 and 259 mites/sq. inch on Washington navel orange and $185 \& 239$ mites/sq. inch on common Mandarin orange, respectively (Table1).

Accordingly, common Balady orange variety was the most susceptible for mite infestation, recorded an average number of 83.16 and 89.02 mites/sq. inch during the two seasons, respectively; while, the less infested variety was common Mandarin orange with a corresponding rate of 42 and 59.5 mites/sq. inch, during the two successive seasons 2013-2014 and 2014-2015, respectively (Table 2).

Generally, the most susceptible variety to the infestation was common Balady orange followed by, Washington navel orange and common Mandarin orange during the two successive years.
This variance in infestation rate of the tenuipalpid mite to citrus varieties may be due to the preference of host selection or the tendency of varieties to tolerant (Ekvised et al., 2006). Therefore, numerous factors appear to contribute in this tendency including, physical and chemical characters of the plants (Goyal et al., 1985 and Childers et al., 2001\&2005), environmental effects and genetic resistance (Laranjeira, et al., 2015 and SánchezVelázquez et al., 2015).

Similarly, tolerance of citrus cultivars to insect infestation has been studied by several investigators (Goyal et al., 1985, Ahmed and Zeidan, 2001, Childers et al., 2003a, Childers et al., 2005, Mata et al., 2010 and Sánchez-Velázquez et al., 2015).

Generally, it can be concluded that different citrus genotype varieties tolerant to insect and mite infestation could play an important role contributing to IPM strategies in integrated crop management programs.

Table (1): Mean number of B. obovatus per square inch on 25 leaves of three tested orange varieties at Qalubia Governorate during the two successive seasons 2013-2014 and 2014-2015.

\begin{tabular}{l|c|c|c|c|c|c}
\hline \multirow{2}{*}{$\begin{array}{c}\text { Sampling } \\
\text { date }\end{array}$} & \multicolumn{3}{|c|}{ Season 2013-2014 } & \multicolumn{3}{c}{ Season 2014-2015 } \\
\cline { 2 - 7 } & $\begin{array}{c}\text { Common } \\
\text { Balady orange }\end{array}$ & $\begin{array}{c}\text { Washington } \\
\text { navel orange }\end{array}$ & $\begin{array}{c}\text { Common } \\
\text { Mandarin orange }\end{array}$ & $\begin{array}{c}\text { Common } \\
\text { Balady orange }\end{array}$ & $\begin{array}{c}\text { Washington } \\
\text { navel orange }\end{array}$ & $\begin{array}{c}\text { Common } \\
\text { Mandarin orange }\end{array}$ \\
\hline October & 42.00 & 34.00 & 27.00 & 51.67 & 42.00 & 33.00 \\
\hline November & 18.00 & 10.00 & 7.00 & 23.33 & 15.00 & 11.00 \\
\hline December & 1.00 & 0.00 & 3.00 & 1.67 & 0.00 & 4.00 \\
\hline January & 0.00 & 0.00 & 0.00 & 0.00 & 0.00 & 0.00 \\
\hline February & 0.00 & 0.00 & 0.00 & 0.00 & 0.00 & 0.00 \\
\hline March & 4.00 & 6.00 & 1.00 & 7.00 & 7.00 & 1.00 \\
\hline April & 9.00 & 9.00 & 6.00 & 16.33 & 13.00 & 8.00 \\
\hline May & 58.00 & 45.00 & 34.00 & 71.67 & 62.00 & 49.00 \\
\hline June & 122.00 & 95.33 & 53.00 & 157.33 & 145.67 & 82.00 \\
\hline July & 213.00 & 134.00 & 85.00 & 241.33 & 231.00 & 128.00 \\
\hline August & 261.00 & 219.67 & 185.00 & 298.33 & 259.00 & 239.00 \\
\hline September & 270.00 & 138.00 & 103.00 & 199.67 & 173.00 & 159.00 \\
\hline Total & 998 & 691 & 504 & 1068.33 & 947.667 & 714 \\
\hline Mean & 83.16 & 57.5 & 42 & 89.02 & 78.9 & 59.5 \\
\hline
\end{tabular}

Table (2): Mean number of B. obovatus per square inch on 25 leaves of three tested orange varieties under field conditions at Qalubia Governorate during two seasons 2013-2014 and 2014-2015.

\begin{tabular}{|c|c|c|c|c|c|c|c|c|}
\hline & & $\begin{array}{c}\text { Common } \\
\text { Balady orange }\end{array}$ & $\begin{array}{l}\text { Washington } \\
\text { navel orange }\end{array}$ & $\begin{array}{c}\text { Common } \\
\text { Mandarin orange }\end{array}$ & Mean & $\mathrm{F}$ & $\mathrm{P}$ & LSD \\
\hline \multirow{4}{*}{ 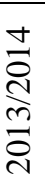 } & Oct.-Des. & 20.33 & 14.67 & 12.33 & 15.78 & 137.58 & 0.0002 & 1.38 \\
\hline & Mar.-May & 23.67 & 20.00 & 13.67 & 19.11 & 128.75 & 0.0002 & 1.75 \\
\hline & Jun.-Sep. & 216.50 & 146.75 & 106.50 & 156.58 & 1467.25 & 0.0000 & 5.71 \\
\hline & Mean & 83.16 & 57.5 & 42 & 60.89 & 1630.38 & 0.0000 & 2.02 \\
\hline \multirow{4}{*}{ 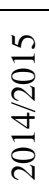 } & Oct.-Des. & 25.56 & 19.00 & 16.00 & 17.00 & 23.7699 & 0.006 & 3.934 \\
\hline & Mar.-May & 31.67 & 27.33 & 19.33 & 22.00 & 93.1548 & 0.0004 & 2.546 \\
\hline & Jun.-Sep. & 224.17 & 202.17 & 152.00 & 168.72 & 812.968 & 0 & 5.05 \\
\hline & Mean & 89.02 & 78.9 & 59.5 & 75.81 & 14897.45 & 0 & 0.481 \\
\hline
\end{tabular}




\section{REFERENCES}

Ahmed, M. K. A. and Zeidan, M. S. 2001. Yield and quality of two citrus cultivars (Arachis hypogaea L.) as affected by methods of potassium application. Egypt. J. Appl. Sci., 16 (7): 114-126.

Childers, C. C.; French, J. V. and Rodrigues, J. C. 2003. Brevipalpus californicus, B. obovatus, B. phoenicis, and B. lewisi (Acari: Tenuipalpidae): a review of their biology, feeding injury and economic importance. Exp. Appl. Acarol., 30: 528.

Childers, C. C.; McCoy, C. W.; Nigg, H. N.; Stansly, P. A. and Rogers, M. E. 2005. Florida citrus pest management guide: rust mites, spider mites, and other phytophagous mites. EDIS. http://edis.ifas.ufl.edu/cg002.

Ekvised, S.; Jogloy, S.; Akkasaeng, C.; Keeratikasikorn, M.; Kesmala, T.; Buddhasimma, I. and Patanothai, A. 2006. Field evaluation of screening procedures for thrips resistance in peanut. Asian J. Plant Sci., 5: 338-346.

Goyal, M.; Sadana, G. L. and Sharma, N. K. 1985. Influence of temperature on the development of Brevipalpus obovatus (Acarina: Tenuipalpidae). Entomon., 10: 125-129.

Laranjeira, F. F.; Silva, S. X.; de Andrade, E.C.; Almeida Dde, O.; da Silva, T. S.; Soares, A. C. and Freitas-Astúa, J. 2015. Infestation dynamics of Brevipalpus phoenicis (Geijskes) (Acari: Tenuipalpidae) in citrus orchards as affected by edaphic and climatic variables, Exp. Appl. Acarol., 66 (4): 491-508.

Mata, J.; Setamou, M.; French, V. J. and Louzada, E. 2010. Molecular fingerprinting and population dynamics of Brevipalpus mites on Texas citrus. Ann. Entomol. Soc. Ame., 103: 898-907.

Muma, M. H. 1975. Mites associated with citrus in Florida. Univ. Fla. Agric. Exp. Sta. Bull. 640A.

Ochoa, R.; Aguilar, H. and Vargas, C. 1994. Phytophagous mites of Central America: an illustrated guide. CATIE, Turrialba, Costa Rica, 234 pp.

Rodrigues, J. C. V. 2000. Relacoes patogeno-vetorplanta no sistema leprose dos citros. Ph. D. Thesis, Centro de Energia Nuclear na Agricultura, da Universidade de Sao Paulo, Piracicaba, Brazil.

Sánchez-Velázquez, E. J.; Santillán-Galicia, M. T.; Novelli, V. M. ; Nunes, M. A.; Mora-Aguilera, G.; Valdez Carrasco, J. M. 2015. Diversity and Genetic Variation among Brevipalpus Populations from Brazil and Mexico. PLOSONE 10(7): e 0133861. Doi: 10.1371/journal. pone.0133861.

Smith Meyer, M .K. P. 1981. Mite pests of crops in Southern Africa. Plant Prot. Res. Inst. Sci. Bull., 397. 